\title{
Problematika Normatif Jaminan Hak-Hak Pekerja Dalam Undang-Undang Nomor 11 Tahun 2020 Tentang Cipta Kerja
}

\author{
Muh Sjaiful \\ m.sjaiful_fh@uho.ac.id \\ Universitas Halu Oleo
}

Keywords:
The Omnibus
Bill; The Legal
Perception; The
worker's Rights.

Kata Kunci: Abstract

The purpose of this research is to analyze the contents of the articles on Omnibus Law if it has provided guaranteed rights protection for workers. The next objective is to analyze the philosophical concept that underlies the characteristics of the articles on such regulation, so that is considered not egalitarian and accommodate guarantees of workers' rights. This research uses a method with the type of normative legal research. The approach is a conceptual philosophical approach and a statute approach. This study also uses a sociological legal approach as a tool in the type of normative legal research. The results of the research show that the Omnibus Law still contains a number of normative problems, namely that it does not guarantee legal certainty for the protection of workers' rights, such as the determination of proper wages and the appropriateness of severance pay. Likewise, the provisions concerning layoffs, the law only accommodates the interests of employers so that it may imply the unilateral layoff of workers. The philosophical concept of the Employment Creation Act, is still co-opted by the liberalistic economic spirit which is the fundamental basis for the the law so that is what has reaped rejection by the majority of the public towards the Omnibus Law.

Undang-Undang Tujuan penelitian adalah untuk menganalisis muatan pasal-pasal tentang Cipta Lapangan Ketenagakerjaan yang termaktub dalam Undang-Undang Nomor 11 Tahun Kerja; Persepsi 2020 tentang Cipta Kerja bila telah memberikan jaminan hak bagi pekerja. Hukum; Hak-Hak Tujuan selanjutnya adalah untuk menganalisis konsep filosofis yang melandasi Pekerja. karakteristik pasal-pasal tentang Ketenagakerjaan dalam Undang-Undang Nomor 11 Tahun 2020 tentang Cipta Kerja, sehingga dianggap tidak egaliter serta mengakomodasikan jaminan hak-hak pekerja. Penelitian ini menggunakan metode dengan tipe penelitian hukum normatif. Pendekatannya adalah pendekatan filosofis konseptual dan pendekatan undang-undang. Penelitian ini juga menggunakan pendekatan hukum sosiologis sebagai alat bantu dalam tipe penelitian hukum normatif. Hasil penelitian menunjukkan bahwa UndangUndang Cipta Lapangan Kerja masih menyimpan sejumlah problematika normatif, yakni belum memberikan jaminan kepastian hukum bagi jaminan hakhak pekerja, semisal penetapan upah yang layak dan kelayakan besaran pesangon. Begitu juga ketentuan tentang PHK, undang-undang hanya mengakomodir kepentingan pengusaha sehingga dapat berimplikasi PHK terhadap buruh/ pekerja secara sepihak. Konsep filosofis Undang-Undang Cipta lapangan Kerja, masih terkooptasi spirit ekonomi liberalistik yang menjadi basis fundamental kelahiran undang-undang tersebut, sehingga Inilah yang menuai penolakan sebahagian besar masyarakat terhadap Undang-Undang Nomor 11 Tahun 2020 
Muh Sjaiful: Problematika Normatif Jaminan...

\section{Pendahuluan}

Pemerintah Indonesia telah memberlakukan Undang-Undang Nomor 11 Tahun 2020 tentang Cipta Kerja. Tujuan pemberlakuan undang-undang ini, menurut Kementerian Keuangan Indonesia, sebagaimana dilangsir, ${ }^{1}$ adalah untuk menciptakan lapangan kerja seluas-luasnya dan merata di seluruh wilayah Indonesia dalam rangka memenuhi hak atas penghidupan yang layak melalui kemudahan dan perlindungan UMKM, peningkatan ekosistem investasi kemudahan berusaha, peningkatan perlindungan kesejahteraan pekerja kemudian investasi pemerintah dan percepatan proyek strategis nasional.

Undang-Undang Nomor 11 Tahun 2020 tentang Cipta Kerja, merupakan kristalisasi regulasi yang menggabungkan beberapa aturan yang substansi pengaturannya berbeda, menjadi satu payung hukum. Artinya, Undang-undang Cipta Kerja ini, telah mengakomodir beberapa undang-undang menjadi satu paket antara lain, undang-undang perpajakan, undang-undang ketenagakerjaan, undang-undang kehutanan, undang-undang lingkungan, undang-undang zonasi perairan Indonesia serta undang-undang pemberdayaan usaha menengah kecil, dan beberapa peraturan undang-undang lainnya yang tak dapat dirinci dalam tulisan ini. Pemerintah punya persepsi sendiri untuk memberlakukan UndangUndang Nomor 11 Tahun 2020 tentang Cipta Kerja, dengan alasan untuk perbaikan ekonomi nasional Indonesia yang semakin terpuruk. ${ }^{2}$

Pada sisi lain, pemberlakuan Undang-Undang Nomor 11 Tahun 2020 tentang Cipta Kerja, mendapat penolakan dari sebahagian besar masyarakat Indonesia dengan tingkat persepsi hukum yang berbeda-beda, dari setiap klaster masyarakat, yakni klaster akademisi, klaster buruh/pekerja, klaster mahasiswa, klaster guru, dan klaster ulama. Setiap klaster memiliki persepsi yang berbeda, tetapi semua klaster warga masyarakat Indonesia tersebut mempunyai tujuan

1 Kementerian Keuangan Republik Indonesia, 'Dikunjungi' (RUU Cipta Lapangan Kerja Mulai Dibahas dengan Badan Legislasi DPR) <https://www.kemenkeu.go.id/publikasi/berita/ruu-ciptakerja-mulai-dibahas-dengan-badan-legislasi-dpr/>.

2 Kementerian Koordinator Bidang Perekonomian Republik Indonesia, Omnibus Law Cipta Lapangan Kerja (2020). 
yang sama yaitu menolak kehadiran Undang-Undang Cipta Kerja, terutama secara spesifik pengaturan tentang perlindungan hak-hak bagi pekerja.

Semua klaster mempunyai alasan bahwa muatan undang-undang cipta kerja, terutama menyangkut regulasi jaminan hak-hak bagi pekerja, sejatinya belum memberikan jaminan keadilan dan kesejahteraan bagi para pekerja di Indonesia. Undang-undang ini menurut para klaster, terutama pengaturan tentang ketenagakerjaan hanya memihak kepentingan para majikan atau pemilik perusahaan.

Sudut pandang tulisan ini, hanyalah menyoroti spesifik tentang Ketenagakerjaan, sebagaimana diatur dalam Bab IV Ketenagakerjaan yang mengakomodir 4 (empat) undang-undang yaitu Undang-Undang Nomor 13 Tahun 2003 tentang Ketenagakerjaan; Undang-Undang Nomor 40 Tahun 2004 tentang Sistem Jaminan Sosial; Undantg-Undang Nomor 24 Tahun 2011 tentang Badan Penyelenggara Jaminan Sosial; dan Undang-Undang Nomor 18 Tahun 2017 tentang Perlindungan Pekerja Migran Indonesia. Lebih khusus lagi, yang disoroti adalah pasal-pasal yang mengatur tentang Ketenagakerjaan terkait dengan perlindungan jaminan hak-hak pekerja.

Atas dasar itulah, artikel penelitian adalah terkonsentrasi pada tujuan untuk menganalisis muatan pasal-pasal tentang Ketenagakerjaan yang terkandung dalam Undang-Undang Nomor 11 Tahun 2020 tentang Cipta Kerja, bila telah memberikan perlindungan jaminan hak bagi pekerja. Tujuan selanjutnya adalah untuk menganalisis konsep filosofis yang melandasi karakteristik pasal-pasal tentang Ketenagakerjaan dalam Undang-Undang Nomor 11 Tahun 2020 tentang Cipta Kerja, sehingga dianggap tidak egaliter serta mengakomodasikan jaminan hak-hak pekerja.

\section{Metodologi Penelitian}

Sesuai dengan karakteristik penelitian ini, yakni tipe penelitian hukum normatif, maka metodologi yang digunakan untuk menganalisis isu utama penelitian adalah dengan menggunakan pendekatan filosofis konseptual dan pendekatan undang-undang. Dua pendekatan ini, sudah paling cocok, sebab 
Muh Sjaiful: Problematika Normatif Jaminan...

problematika muatan pasal-pasal tentang Ketenagakerjaan dalam UndangUndang Nomor 11 Tahun 2020 tentang Cipta Kerja, terutama yang mengatur tentang jaminan hak-hak pekerja, pada hakikatnya dengan menggunakan pisau analisis konseptual filosofis, serta bagaimana wujud undang-undang tersebut telah melegitimasi jaminan kehidupan yang layak bagi para pekerja itu sendiri. Sebagai penelitian hukum dengan tipe hukum normatif, tak dapat dipungkiri, penulis juga menggunakan pendekatan hukum sosiologis (sociological jurisprudence). Pendekatan hukum sosiologis ini sesungguhnya kata Irwansyah, ${ }^{3}$ bukanlah bermaksud mendeviasi tipe penelitian hukum normatif yang memiliki karakteristik preskriptif, tetapi justeru pendekatan hukum sosiologis, adalah alat bantu menggali nilai-nilai hukum normatif yang berakar dari keyakinan hukum masyarakat, sebagaimana di Indonesia penggalian nilai-nilai hukum normatif yang digali dari keyakinan transendental mayoritas masyarakat Indonesia, yakni Ketuhanan Yang Maha Esa dan keadilan sosial yang oleh the founding fathers bangsa ini menyepakatinya secara politik dalam kristalisasi nilai-nilai yang terwujud dalam Pancasila dan Undang-Undang Dasar 1945.

\section{Meletakkan Persepsi Hukum Masyarakat Indonesia terhadap Perlindungan Hak-Hak Pekerja Dalam Undang-Undang Cipta Kerja}

Friedrich Carl Von Savigny, ${ }^{4}$ merupakan salah seorang tokoh hukum yang cukup popoler, penganut mazhab hukum sejarah (historicaljurisprudence). Dia merumuskan bahwa hukum sejatinya merupakan formulasi nilai-nilai kesadaran masyarakat yang tumbuh dan berkembang sesuai dengan perkembangan masyarakatnya. Tesis Von Savigny tersebut lalu menghasilkan kesimpulan bahwa hukum mencerminkan jiwa suatu bangsa (volksgeist). Penjelasan Von Savigny, paling tidak memberikan sebuah gagasan bahwa penormaan suatu produk

\footnotetext{
3 Irwansyah dan Ahsan Yunus, Penelitian Hukum (Pilihan Metode E Praktik Penulisan Artikel (Mirra Buana Media 2000).[175-180].

4 M Zulfa Aulia, 'Friedrich Carl Von Savigny Tentang Hukum: Hukum Sebagai Manifestasi Jiwa Bangsa' (2020) 3 Undang:Jurnal Hukum <https://ujh.unja.ac.id/index.php/home/article/ view/95> DOI: 10.22437/Ujh.3.1.[201-236].
} 
hukum yang berlaku disuatu masyarakat atau bangsa, paling tidak seharusnya mencerminkan nilai-nilai hukum yang hidup (the living law) sebagai keyakinan ideologis dalam konteks kehidupan masyarakat.

Pada konteks demikian itu, sesungguhnya harus bisa dipahami, bahwa penormaan nilai-nilai hukum yang dilegalisasi secara formal dalam produk hukum tertulis, secara prinsip sebagaimana yang diungkap Peter Mahmud ${ }^{5}$ Marzuki, seharusnya bisa menjamin eksistensi hidup manusia. Tatkala merumuskan apa yang dinisbatkan sebagai penormaan nilai-nilai yang menjamin eksistensi hidup manusia, maka tentu saja harus ada patokan nilai standar moral yang berlaku sebagai nilai-nilai yang hidup di tengah masyarakat. Dari titik pandang inilah maka keberlakuan hukum, sebagaimana ungkapan Sudikno Mertokusumo, ${ }^{6}$ tidak boleh mengabaikan nilai-nilai empiris berupa nilai-nilai ideologi hukum yang berlaku di tengah masyarakat. ${ }^{7}$

Sehubungan dengan itu, maka menurut penulis, pengukuran penormaan suatu produk hukum yang diundangkan, sebagai wujud untuk mengakomodasikan niali-nilai hukum yang hidup ditengah masyarakat sebagai the living law, hal yang sangat penting adalah meletakkan persepsi hukum masyarakat terhadap muatan normatif sebuah produk hukum tertulis yang diberlakukan. Persepsi hukum, dengan mengutip pandangan Emile Durkheim, ${ }^{8}$ meskipun tidak boleh mendasarkan oleh opini umum masyarakat tetapi harus melalui representasi negara dimana masyarakat itu dibangun. Namun bagaimanapun juga, persepsi hukum sejatinya equivalen dengan ideologi hukum masyarakat yang terkristalisasi baik sebagai sebuah hukum kebiasaan (customary) maupun dalam konsitusi (grundnorm) maupun filosofi dasar (Philosopsche Grondslag) suatu negara. ${ }^{9}$

5 Peter Mahmud Marzuki, Pengantar Ilmu Hukum (Kencana 2008).[42].

6 Sudikno Mertokusumo, Penemuan Hukum : Sebuah Pengantar (Liberty 2000).[38].

7 Christiani Widowati, 'Hukum Sebagai Norma Sosial Memiliki Sifat Mewajibkan' (2013) 4 Adil: Jurnal Hukum.[157-158].

8 Emile Durkheim dkk, Sociology and Philosophy, Diterjemahkan oleh DF. Pocock, Routledge Revivals (1953).[32-32].

9 Suparman Usman, Pokok-Pokok Filsafat Hukum (2010).[164]. 
Muh Sjaiful: Problematika Normatif Jaminan...

Konsep tentang persepsi hukum dalam pandangan para ahli hukum, sesungguhnya terdapat beragam pendapat. Meskipun terdapat keragaman pendapat, tetapi terdapat kesamaan pendapat diantara mereka tentang unsur terkait dengan definisi persepsi hukum itu sendiri. Titik persamaan para ahli hukum dalam mendefinisikan persepsi hukum yakni persepsi hukum dirumuskan sebagai pandangan serta opini warga masyarakat terhadap muatan sebuah produk regulasi yang rencana dan sedang diberlakukan oleh pemerintah. Pandangan atau opini tentang undang-undang yang diberlakukan pemerintah, kemudian berdampak kepada tingkat prilaku masyarakat terhadap undang-undang yang diberlakukan, seperti tingkat ketaatan kepada hukum. Pengukuran tingkat ketaatan masyarakat dapat dideteksi melalui sikap menolak atau menerima kehadiran undang-undang tersebut. Jika tingkat penerimaan masyarakat terhadap undang-undang yang berlaku cukup tinggi berarti tingkat kesadaran masyarakat berpengaruh positif, tetapi apabila tingkat penolakan masyarakat cukup tinggi terhadap undangundang berarti tingkat kesadaran masyarakat berpengaruh negatif. ${ }^{10}$

Tingkat penerimaan dan penolakan masyarakat terhadap undang-undang yang berlaku, pada umumnya terkait dengan keyakinan ideologi hukum sebahagian besar masyarakat terhadap undang-undang yang berlaku. Semakin besar kesesuaian ideologi hukum masyarakat dengan undang-undang yang berlaku maka tingkat penerimaan masyarakat terhadap undang-undang yang berlaku juga semakin besar. Sebaliknya, semakin besar ketidaksesuaian ideologi hukum masyarakat dengan undang-undang yang berlaku, maka juga semakin besar tingkat penolakan masyarakat terhadap pemberlakuan undang-undang tersebut. ${ }^{11}$

Tingkat penerimaan dan penolakan masyarakat terhadap undang-undang, selain terkait ideologi hukum yang dianut, juga terkait dengan muatan nilai-nilai keadilan yang terkandung dalam undang-undang tersebut. Bila muatan undangundang dalam tataran penerapannya memberikan ketidakadilan bagi masyarakat

${ }_{10}$ Atang Hermawan Usman, 'Kesadaran Hukum Masyarakat Dan Pemerintah Sebagai Faktor Tegaknya Negara Hukum Di Indonesia' (2014) 30 Jurnal Wawasan Hukum.[28-30].

${ }_{11}$ Peni Jati Setyowati, 'Fungsi Filsafat, Agama, Ideologi Dan Hukum Dalam Perkembangan Politik Di Indonesia’ (2016) 31 Yuridika.[94-99]. 
maka sudah pasti undang-undang tersebut mendapat penolakan besar-besaran dari warga masyarakat. Meskipun definisi adil atau tidak adil masih merupakan perdebatan dikalangan para ahli filsafat, tetapi paling tidak nilai-nilai keadilan biasanya berujung kepada kepuasan mendapatkan perlakuan hukum yang sama tanpa memandang status sosial serta kepuasan warga masyarakat memperoleh kesejahteraan ekonomi dari negara.

Dari penjelasan tersebut maka persepsi hukum selalu terkait dengan keyakinan hukum serta pandangan hukum masyarakat terhadap penerapan sebuah produk hukum yang diberlakukan oleh pemerintah. Keyakinan dan pandangan hukum, juga selalu dikaitkan dengan manfaat keadilan yang diberikan oleh undang-undang. Masyarakat berpikir untuk menolak suatu undang-undang kalau undang-undang yang diberlakukan tidak memberikan manfaat keadilan, diskriminatif, dan zalim. Sebuah undang-undang memiliki nilai positif apabila dalam penerapannya dapat memuaskan rasa keadilan masyarakat terutama dapat menjamin kesejahteraan ekonomi masyarakat, tanpa memandang nilai keyakinan ideologi yang dianut masing-masing warga masyarakat.

Pada titik inilah, maka peletakan persepsi hukum dalam kerangka penormaan hak-hak pekerja dalam Undang-Undang Nomor 11 Tahun 2020 tentang Cipta Kerja yang diberlakukan pemerintah, menjadi relevan ketika mencermati ada hubungan variabel yang begitu kuat antara muatan pasal-pasal tentang hak-hak pekerja sebagaimana termaktub dalam Undang-Undang Nomor 11 Tahun 2020 tentang Cipta Kerja dengan apa yang menjadi cita-cita hukum masyarakat Indonesia sebagai sebuah kesadaran hukum yang merupakan Philosopsche Grondslag dalam Pancasila dan UUD 1945.

Sehubungan dengan itu, maka pada konteks analisis ini, adalah cukup relevan menurut penulis untuk ditelaah terkait dengan problematika pasal-pasal yang mengatur tentang hak-hak pekerja pada Bab tentang Ketenagakerjaan dalam Undang-Undang Nomor 11 Tahun 2020 tentang Cipta Kerja. Peletakkan analisis terkait persepsi hukum, adalah untuk meletakkan kerangka kajian UndangUndang Nomor 11 Tahun 2020 tentang Cipta Kerja dalam perspektif normatif 
Muh Sjaiful: Problematika Normatif Jaminan...

tentunya, sebagaimana meminjam ungkapan Irwansyah ${ }^{12}$ bahwa persepesi hukum ini adalah untuk meletakkan hukum normatif dalam bingkai hukum sosiologis (sociological jurisprudence), sebagai sebuah postulat yang mana problematika normatif muatan pasal dalam Undang-Undang Nomor 11 Tahun 2020 tentang Cipta Kerja, tampaknya masih bertentangan secara diametral dengan cita-cita hukum masyarakat Indonesia yang menghendaki perlindungan hak-hak pekerja sebagaimana terkrstalisasi dalam Pancasila sebagai Philosopsche Grondslag Bangsa Indonesia dan UUD 1945 sebagai grundnorm atau norma dasar yang derivasi asasasas dalam konstitusi yang tidak boleh bertentangan dengan undang-undang yang ada dibawahnya (asas lex superior derogat legi inferior). ${ }^{13}$

Kehadiran Undang-Undang Nomor 11 Tahun 2020 tentang Cipta Kerja, telah memicu gejolak sosial di tengah masyarakat Indonesia, terutama muatan pasalpasal yang mengakomodir jaminan hak-hak pekerja. Persepsi hukum masyarakat Indonesian terhadap hadirnya undang-undang tersebut, menimbulkan berbagai penolakan dengan pandangan bahwa Undang-Undang Nomor 11 Tahun 2020 tentang Cipta Kerja, terutama menyangkut perlindungan hak-hak pekerja, tidaklah membawa dampak kemanfaatan hukum, yang berpihak terhadap kepentingan perlindungan hak-hak para pekerja atau kaum buruh Indonesia dalam hubungan kontraktual dengan pihak majikan.

Penolakan masyarakat terhadap kehadiran Undang-Undang Nomor 11 Tahun 2020 tentang Cipta Kerja, merupakan sebuah fakta hukum yang dari sudut pandang kajian hukum sosiologis (sociological jurisprudence), yang sejatinya merupakan data pendukung untuk menyimpulkan bahwa sesungguhnya Undang-Undang Nomor 11 Tahun 2020 tentang Cipta Kerja, masih menyimpan sejumlah problematika normatif, khususnya pasal-pasal jaminan hak-hak bagi pekerja, yang sangat bertentangan secara diametral dengan cita hukum masyarakat Indonesia.

\footnotetext{
${ }^{12}$ Irwansyah dan Ahsan Yunus (n 3).

${ }^{13}$ Maria Farida Indrati S, Ilmu Perundang-Undangan 1: Jenis Fungsi Dan Materi Muatan (Kanisius 2007).[205].
} 
Hasil penjajakan penulis secara empiris pada berbagai sumber berita on line yang dihimpun, terdeskripsi penolakan berbagai elemen masyarakat terhadap kehadiran Undang-Undang Cipta Lapangan Kerja. Unsur-unsur elemen masyarakat dimaksud, penulis mengkategorisasikannya berdasarkan kepada beberapa klaster, yakni: klaster mahasiswa, klaster kalangan akademis, klaster buruh/ pekerja, klaster guru, danklaster tokoh agama. Penulis mendeskripsikannya pada tabel berikut:

Tabel 1. Penolakan Masyarakat Terhadap Undang-Undang Cipta Lapangan Kerja Berdasarkan Klaster

\begin{tabular}{|c|c|c|c|}
\hline No & Klaster & Afiliasi Organisasi & Keterangan \\
\hline 1 & Buruh/Pekerja & $\begin{array}{l}\text { Konfederasi Serikat Pekerja } \\
\text { Indonesia }\end{array}$ & \\
\hline 2 & Akademisi & 67 Akademisi & $\begin{array}{l}\text { Perwakilan Universitas Braw- } \\
\text { ijaya, IPN, Unsoed, Unpad, } \\
\text { UNJ, Universitas Andalas, } \\
\text { Pusham Ubaya, Universitas } \\
\text { Bengkulu, Universitas Mula- } \\
\text { warman, Universitas Negeri } \\
\text { Padang, FH Universitas Air- } \\
\text { langga, FH UI, FH Universitas } \\
\text { Lampung, Universitas Syiah } \\
\text { Kuala, FH Universitas Ichsan } \\
\text { Gorontalo, FH Universitas } \\
\text { Bung Hatta. }\end{array}$ \\
\hline 3 & Mahasiswa & $\begin{array}{l}\text { Aliansi Badan Eksekutif Ma- } \\
\text { hasiswa se-Bogor, Jakarta, } \\
\text { mahasiswa di Samarinda, } \\
\text { termasuk di } 18 \text { Provinsi Di } \\
\text { Indonesia }\end{array}$ & $\begin{array}{l}\text { Jakarta, bentrok massa dan } \\
\text { polisi juga terjadi di Yogyakar- } \\
\text { ta, Malang, Medan, Kendari. }\end{array}$ \\
\hline 4 & Guru & $\begin{array}{l}\text { Koordinator Perhimpunan } \\
\text { Untuk Pendidikan dan Guru } \\
\text { (P2G) }\end{array}$ & $\begin{array}{l}\text { Nama Kordinator Satriwan } \\
\text { Salim }\end{array}$ \\
\hline 5 & Tokoh Agama & $\begin{array}{l}\text { Muhammadiyah dan Pen- } \\
\text { gurus Besar Nahdlatul Ula- } \\
\text { ma (PBNU) }\end{array}$ & $\begin{array}{l}\text { Ketua Bidang Hukum dan } \\
\text { HAM PP Muhammadiyah } \\
\text { Busyro Muqoddas dan Ketua } \\
\text { Umum Pengurus Besar Nah- } \\
\text { dlatul Ulama (PBNU) KH Said } \\
\text { Aqil Siroj. }\end{array}$ \\
\hline
\end{tabular}

Sumber: Dari berbagai situs berita on line, 2020. Juga rangkuman hasil penelitian Muhammad Fakhrur Razy dan Muhammad Fedryansyah. ${ }^{14}$

14 Muhammad Fakhrur Razy dan Muhammad Fedryansyah, 'Konflik Gerakan Masyarakat Sipil Dan Pemerintah Dalam Proses Penyusunan Rancangan Undang-Undang Omnibus Law 2020' (2020) 2 Jurnal Kolaborasi Resolusi Konflik.[74-85]. 
Muh Sjaiful: Problematika Normatif Jaminan...

Tabel tersebut, merupakan bukti empiris bahwa persepsi hukum warga masyarakat yang direpresentasikan masing-masing klaster, menyatakan suara penolakan sama yakni undang-undang tersebut dipandang tidak memihak kepentingan para pekerja, tidak adil, dan hanya menguntungkan kalangan pengusaha. Satu hal yang menjadi kegundahan dari penolakan warga masyarakat terhadap kehadiran Undang-Undang Cipta Kerja, terutama menyangkut jaminan hak-hak pekerja, sebagaimana diungkap Louis IX King, ${ }^{15}$ dan kawan-kawan, dalam risalah hasil penelitian yang tidak dipublikasikan adalah Undang-Undang Cipta Kerja, membuka ruang perbudakan modern lewat fleksibilitas tenaga kerja. Implikasinya buruh tidak lagi punya daya tawar untuk memperbaiki kondisi kerja. Selain itu, kemudahan pengusaha untuk merekrut dan memecat pekerja membuat kondisi kerja semakin buruk.

Menggeledah Problematika Normatif Muatan Pasal tentang Ketenagakerjaan dalam Undang-Undang Nomor 11 Tahun 2020 tentang Cipta Kerja, yang Belum Mengakomodir Jaminan Hak-Hak Pekerja

Pada uraian sebelumnya, penulis menjelaskan bahwa Undang-Undang Nomor 11 Tahun 2020 tentang Cipta Kerja, merupakan kristalisasi dari berbagai undang-undang menjadi satu paket. Untuk risalah penelitian ini secara spesifik, hanya menyoroti beberapa pasal tentang Ketenagakerjaan yang secara filosofis, belum memberikan perlindungan hak-hak bagi pekerja.

Dalam Undang-Undang Nomor 11 Tahun 2020 tentang Cipta Kerja, pada Bab IV tentang Ketenagakerjaan, sebagaimana yang diatur dalam Pasal 81 menyebutkan bahwa:

“Beberapa ketentuan dalam Undang-Undang Nomor 13 Tahun 2003 tentang Ketenagakerjaan (Lembaran Negara Republik Indonesia Tahun 2003 Nomor 39, Tambahan Lembaran Negara Republik Indonesia 4279) diubah".

${ }^{15}$ Louis IX King, "Selayang Pandang Omnibus Law”, Risalah Tidak Dipublikasikan, Badan Ekesekutif Mahasiswa Universitas Sanata Dharma Kabinet Solidaritas Aksi, 2020. 
Ketentuan tersebut, merupakan dalil dogmatik bahwa keberadaan UndangUndang Nomor 13 Tahun 2003 tentang Ketenagakerjaan, secara substansi beberapa pasal akan dirubah dan beberapa pasal bakal dihapus oleh UndangUndang Nomor 11 Tahun 2020 tentang Cipta Kerja. Paling tidak, ada 68 item yang dirubah dan diganti oleh Undang-Undang Nomor 11 Tahun 2020 tentang Cipta Kerja, yang penulis merangkumnya secara ringkas pada tabel berikut ini:

Tabel 2. Beberapa Pasal yang dirubah dan dihapuskan dalam Undang-Undang Nomor 13 Tahun 2003 oleh Undang-Undang Nomor 11 Tahun 2020 tentang Cipta Kerja

\begin{tabular}{|c|c|c|}
\hline No & $\begin{array}{l}\text { Ketentuan Dalam Pasal Undang- } \\
\text { Undang Nomor } 11 \text { Tahun } 2020 \\
\text { tentang Cipta Kerja }\end{array}$ & $\begin{array}{c}\text { Ketentuan Dalam Undang-Undang } \\
\text { Nomor } 13 \text { Tahun } 2003 \text { Yang dirubah } \\
\text { dan Dihapus }\end{array}$ \\
\hline 1 & Pasal 81 & $\begin{array}{c}\text { Perubahan Pasal } 13 \text { tentang Lembaga } \\
\text { Pelatihan Kerja }\end{array}$ \\
\hline 2 & Pasal 81 & $\begin{array}{c}\text { Perubahan Pasal } 14 \text { tentang Kewajiban } \\
\text { memiliki perizinan usaha bagi Lembaga } \\
\text { Pelatihan Kerja }\end{array}$ \\
\hline 3 & Pasal 81 & $\begin{array}{c}\text { Perubahan Pasal } 37 \text { tentang Penempatan } \\
\text { Tenaga Kerja }\end{array}$ \\
\hline 4 & Pasal 81 & $\begin{array}{l}\text { Perubahan Pasal } 42 \text { tentang Kewajiban } \\
\text { Pemberi Kerja memiliki rencana } \\
\text { penggunaan tenaga kerja dan pelarangan } \\
\text { bagi tenaga kerja asing }\end{array}$ \\
\hline 5 & Pasal 81 & Pasal 43 dihapus \\
\hline 6 & Pasal 81 & Pasal 44 dihapus \\
\hline 7 & Pasal 81 & $\begin{array}{c}\text { Perubahan Pasal } 45 \text { tentang Kewajiban } \\
\text { Bagi Pekerja Asing }\end{array}$ \\
\hline 8 & Pasal 81 & Pasal 46 dihapus \\
\hline 9 & Pasal 81 & $\begin{array}{c}\text { Perubahan Pasal } 47 \text { tentang Kewajiban } \\
\text { Pemberi Kerja memberikan kompensasi } \\
\text { bagi pekerja asing }\end{array}$ \\
\hline 10 & Pasal 81 & Pasal 48 dihapus \\
\hline 11 & Pasal 81 & $\begin{array}{l}\text { Perubahan Pasal } 49 \text { tentang Penggunaan } \\
\text { Tenaga Kerja Asing diatur oleh PP }\end{array}$ \\
\hline 12 & Pasal 81 & $\begin{array}{c}\text { Perubahan Pasal } 56 \text { tentang Perjanjian } \\
\text { Kerja }\end{array}$ \\
\hline 13 & Pasal 81 & $\begin{array}{l}\text { Perubahan Pasal } 57 \text { tentang Perjanjian } \\
\text { Kerja untuk waktu tertentu }\end{array}$ \\
\hline 14 & Pasal 81 & $\begin{array}{l}\text { Perubahan Pasal } 58 \text { tentang masa perco- } \\
\text { baan kerja }\end{array}$ \\
\hline 15 & Pasal 81 & $\begin{array}{l}\text { Perubahan Pasal } 59 \text { tentang kualifikasi } \\
\text { pekerjaan dalam Perjanjian Kerja untuk } \\
\text { waktu tertentu }\end{array}$ \\
\hline
\end{tabular}


Muh Sjaiful: Problematika Normatif Jaminan...

\begin{tabular}{|c|c|c|}
\hline 16 & Pasal 81 & $\begin{array}{l}\text { Perubahan Pasal } 61 \text { tentang berakhirnya } \\
\text { perjanjian kerja }\end{array}$ \\
\hline 17 & Pasal 81 & $\begin{array}{l}\text { Perubahan Pasal } 61 \text { dan Pasal } 62 \text { tentang } \\
\text { kompensasi dan berakhirnya Perjanjian } \\
\text { Kerja untuk waktu tertentu }\end{array}$ \\
\hline 18 & Pasal 81 & Pasal 64 dihapus \\
\hline 19 & Pasal 81 & Pasal 65 dihapus \\
\hline 20 & Pasal 81 & $\begin{array}{l}\text { Perubahan Pasal } 66 \text { tentang hubungan } \\
\text { kerja antara perusahaan dan buruh, upah } \\
\text { buruh, dan perizinan berusaha serta } \\
\text { perlindungan buruh }\end{array}$ \\
\hline 21 & Pasal 81 & $\begin{array}{l}\text { Perubahan Pasal } 77 \text { tentang kewajiban } \\
\text { pengusaha mengenai ketentuan waktu } \\
\text { kerja }\end{array}$ \\
\hline 22 & Pasal 81 & $\begin{array}{l}\text { Perubahan Pasal } 78 \text { tentang kewajiban } \\
\text { pengusaha yang memperkerjakan buruh } \\
\text { melebihi waktu kerja }\end{array}$ \\
\hline 23 & Pasal 81 & $\begin{array}{l}\text { Perubahan Pasal } 79 \text { tentang waktu istra- } \\
\text { hat dan cuti bagi pekerja }\end{array}$ \\
\hline 24 & Pasal 81 & $\begin{array}{l}\text { Perubahan Pasal } 88 \text { tentang upah dan } \\
\text { penghidupan yang layak bagi buruh/ } \\
\text { pekerja }\end{array}$ \\
\hline 25 & Pasal 81 & Perubahan Pasal 88 tentang upah buruh \\
\hline 26 & Pasal 81 & Pasal 89 Dihapus \\
\hline 27 & Pasal 81 & $\begin{array}{l}\text { Pasal } 90 \text { dan Pasal } 91 \text { penyisipan pasal } \\
\text { tentang upah minimum }\end{array}$ \\
\hline 28 & Pasal 81 & $\begin{array}{l}\text { Penyisipan Pasal } 90 \text { dan pasal } 91 \text { tentang } \\
\text { kesepakatan pengusaha dengan buruh } \\
\text { mengenai upah minimum }\end{array}$ \\
\hline 29 & Pasal 81 & Beberapa ketentuan Pasal 91 dihapus \\
\hline 30 & Pasal 81 & $\begin{array}{c}\text { Perubahan Pasal } 92 \text { tentang kewajiban } \\
\text { pengusaha menyusun struktur dan skala } \\
\text { upah }\end{array}$ \\
\hline 31 & Pasal 81 & $\begin{array}{l}\text { Penyisipan pasal } 92 \text { dan pasal } 93 \text { tentang } \\
\text { peninjauan upah dan komponen upah }\end{array}$ \\
\hline 32 & Pasal 81 & $\begin{array}{c}\text { Perubahan Pasal } 94 \text { tentang tunjangan } \\
\text { bagi pekerja }\end{array}$ \\
\hline 33 & Pasal 81 & $\begin{array}{c}\text { Perubahan Pasal } 95 \text { tentang Perusahan } \\
\text { yang dinyatakan pailit }\end{array}$ \\
\hline 34 & Pasal 81 & Pasal 96 dihapus \\
\hline 35 & Pasal 81 & Pasal 97 dihapus \\
\hline 36 & Pasal 81 & $\begin{array}{c}\text { Perubahan Pasal } 98 \text { tentang Dewan } \\
\text { Pengupahan }\end{array}$ \\
\hline 37 & Pasal 81 & Perubahan Pasal 151 tantang PHK \\
\hline 38 & Pasal 81 & $\begin{array}{c}\text { Penyisipan Pasal } 151 \text { dan pasal } 152 \\
\text { tentang berakhirnya hubungan kerja } \\
\text { yang tidak perlu pemberitahuan oleh } \\
\text { pengusaha }\end{array}$ \\
\hline
\end{tabular}




\begin{tabular}{|c|c|c|}
\hline 39 & Pasal 81 & Pasal 152 dihapus \\
\hline 40 & Pasal 81 & $\begin{array}{c}\text { Perubahan Pasal } 153 \text { tentang Pelarangan } \\
\text { Alasan PHK oleh pengusaha }\end{array}$ \\
\hline 41 & Pasal 81 & Pasal 154 dihapus \\
\hline 42 & Pasal 81 & $\begin{array}{l}\text { Penyisipan Pasal } 154 \text { dan Pasal } 155 \\
\text { tentang larangan alasan PHK }\end{array}$ \\
\hline 43 & Pasal 81 & Pasal 155 dihapus \\
\hline 44 & Pasal 81 & $\begin{array}{l}\text { Perubahan Pasal } 156 \text { tentang uang } \\
\text { pesangon }\end{array}$ \\
\hline 45 & Pasal 81 & $\begin{array}{l}\text { Perubahan Pasal } 157 \text { tentang Dasar } \\
\text { Perhitungan uang pesangon }\end{array}$ \\
\hline 46 & Pasal 81 & $\begin{array}{c}\text { Penyisipan pasal } 157 \text { dan Pasal } 158 \\
\text { tentang penyelesaian perselisihan } \\
\text { hubungan industrial }\end{array}$ \\
\hline 47 & Pasal 81 & Pasal 158 Dihapus \\
\hline 48 & Pasal 81 & Pasal 159 dihapus \\
\hline 49 & Pasal 81 & $\begin{array}{c}\text { Perubahan Pasal } 160 \text { tentang buruh yang } \\
\text { melakukan tindak pidana }\end{array}$ \\
\hline 50 & Pasal 81 & Pasal 161 dihapus \\
\hline 51 & Pasal 81 & Pasal 162 dihapus \\
\hline 52 & Pasal 81 & Pasal 163 dihapus \\
\hline 53 & Pasal 81 & Pasal 164 dihapus \\
\hline 54 & Pasal 81 & Pasal 165 dihapus \\
\hline 55 & Pasal 81 & Pasal 166 dihapus \\
\hline 56 & Pasal 81 & Pasal 167 dihapus \\
\hline 57 & Pasal 81 & Pasal 168 dihapus \\
\hline 58 & Pasal 81 & Pasal 169 dihapus \\
\hline 59 & Pasal 81 & Pasal 170 dihapus \\
\hline 60 & Pasal 81 & Pasal 171 dihapus \\
\hline 61 & Pasal 81 & Pasal 172 dihapus \\
\hline 62 & Pasal 81 & Pasal 184 dihapus \\
\hline 63 & Pasal 81 & $\begin{array}{l}\text { Pasal 185, Pasal 186, Pasal 187, Pasal 188, } \\
\text { Pasal } 190 \text { tentang sanksi pidana bagi } \\
\text { pelanggar ketentuan Ketenagakerjaan }\end{array}$ \\
\hline 64 & Pasal 81 & $\begin{array}{l}\text { Penyisipan Pasal } 191 \text { dan pasal } 192 \text { ten- } \\
\text { tang penetapan upah minimum }\end{array}$ \\
\hline
\end{tabular}

Hasil Pencermatan Penulis terhadap pasal-pasal tentang Ketenagakerjaan dalam Undang-Undang Cipta lapangan Kerja

Dengan mencermati beberapa ketentuan dalam Undang-Undang Nomor 11 Tahun 2020 tentang Cipta Kerja, sebagaimana yang ditabulasi penulis, terutama terkait dengan pasal-pasal yang mengatur tentang Ketenagakerjaan, 
Muh Sjaiful: Problematika Normatif Jaminan...

yang terangkum dalam Pasal 81 maka secara filosofis, menurut argumentasi penulis, masih terdapat sejumlah problematika normatif yang bila ditelisik lebih mendalam, belumlah mengakomodir jaminan hak-hak bagi pekerja.

Pada konteks pembahasan ini, penulis hanya menyoal jaminan hak pekerja yang secara pokok, semestinya mendapat jaminan perlindungan hukum, apabila dikaitkan dengan isu yang diangkat dalam Undang-Undang Nomor 11 Tahun 2020 tentang Cipta Kerja, sebagai berikut:

\section{Jaminan Hak Pekerja Atas Upah dan Pesangon}

Penulis memulai pada analisis pengaturan tentang hak pekerja atas upah. Penetapan upah buruh atau pekerja dalam Undang-Undang Nomor 11 Tahun 2020 tentang Cipta Kerja, adalah diserahkan kepada kesepakatan antara majikan dengan buruh serta undang-undang yang berlaku. Ini dinyatakan dalam Bab Ketenaga Kerjaan Pasal 81 Point 25 Penambahan Pasal 88A, sebagai berikut:

4) Pengaturan pengupahan yang ditetapkan atas kesepakatan antara pengusaha dengan pekerja/buruh atau serikat pekerja/serikat buruh tidak boleh lebih rendah dari ketentuan pengupahan yang ditetapkan dalam peraturan perundang-undangan.

5) Dalam hal kesepakatan sebagaimana dimaksud pada ayat (4) lebih rendah atau bertentangan dengan peraturan perundang-undangan, kesepakatan tersebut batal demi hukum dan pengaturan pengupahan dilaksanakan sesuai dengan ketentuan peraturan perundang-undangan.

Ketentuan pasal tersebut, menjadi rujukan bahwa penetapan upah buruh adalah berdasarkan kesepakatan antara pengusaha dengan pekerja/buruh serta ketentuan perundang-undangan. Pengaturan ini secara normatif, membuka peluang penentuan upah yang ditetapkan secara sepihak oleh pengusaha. Ketentuan pasal ini memang tampak akan membuka ruang perdebatan berkepanjangan antara buruh dan majikan soal penentuan upah meskipun kehadiran undang-undang akan menjadi batasan koridor yang menghentikan perdebatan antara buruh dan majikan mengenai penetapan upah. Yang menjadi problemnya menurut penulis adalah muatan pasal tersebut, sangat berpeluang menimbulkan konflik norma antara apa yang ditentukan undang-undang dengan apa yang telah menjadi kesepakatan antara buruh dengan majikan. Padahal 
seharusnya, supaya tidak menimbulkan konflik norma, semestinya undangundang, terutama pada Undang-Undang Nomor 11 Tahun 2020 tentang Cipta Kerja, lebih memberikan penegasan lebih akuntabel tentang standar upah buruh/ pekerja yang lebih menjamin stndar hidup para buruh/majikan.

Selanjutnya, menyangkut penetapan upah minimum, dalam UndangUndang-Undang Nomor 11 Tahun 2020 tentang Cipta Kerja, diatur dalam Pasal 81 untuk penambahan Pasal 88C tentang Ketenagakerjaan point 25, menyatakan bahwa:

1) Gubernur wajib menetapkan upah minimum provinsi;

2) Gubernur dapat menetapkan upah minimum kabupaten/kota dengan syarat tertentu;

3) Upah minimum sebagaimana dimaksud pada ayat (1) dan ayat (2) ditetapkan berdasarkan kondisi ekonomi dan ketenagakerjaan;

4) Syarat tertentu sebagaimana dimaksud pada ayat (2) meliputi pertumbuhan ekonomi daerah dan inflasi pada kabupaten/kota yang bersangkutan.

Ketentuan pasal tersebut, merupakan perubahan pasal sebelumnya dari Undang-Undang Ketenagakerjaan Nomor 23 Tahun 2013 sebelumnya, mengenai penetapan upah minimum. Hal yang paling krusial adalah penetapan upah minimum diserahkan kepada otoritas gubernur serta dengan merujuk kepada pertumbuhan ekonomi daerah dan kondisi inflasi masing-masing daerah. Yang paling krusial menurut argumentasi penulis adalah alasan penentuan upah minimum dengan berlandaskan kepada pertumbuhan dan inflasi ekonomi daerah. Pada konteks jaminan upah buruh atau pekerja maka cara penetapan standar tersebut, sangat kabur sebab penetapan upah minimum buruh semestinya juga dikaitkan dengan profesionalisme atau curah kerja sang buruh berdasarkan manfaat yang diperoleh dari majikan atau perusahaan. Semestinya bukan berpatokan kepada pertumbuhan ekonomi daerah yang sering kali fluktuatif.

Penetapan upah minimum buruh juga diserahkan beradasarkan otoritas masing-masing gubernur. Artinya, bila pengaturan tentang upah minimum, hanya diatur pada level provinsi maka peluang konspirasi antara gubernur dengan pengusaha yang memberi jasa ongkos politik pada saat kampanye pemilihan gubernur, semakin melebar terutama dalam hal penentuan upah 
Muh Sjaiful: Problematika Normatif Jaminan...

minimum provinsi. Selera penentuan upah minimum provinsi, sangat boleh jadi mengikuti selera kepentingan para pengusaha yang memiliki pengaruh cukup kuat dilingkaran elitis kekuasaan gubernur.

Masih tentang standar penentuan upah buruh/pekerja, point 30 Pasal 81, perubahan Pasal 92 tentang Ketenagakerjaan dalam Undang-Undang Nomor 11 Tahun 2020 tentang Cipta Kerja bahwa: “Ketentuan lebih lanjut mengenai struktur dan skala upah diatur dengan Peraturan Pemerintah". Pasal mengandung kekaburan hukum karena tidak ada penjelasan rinci tentang penetapan standar upah, kecuali akan diatur oleh peraturan pemerintah. Ini menurut Sigit Riyanto, dkk, ${ }^{16}$ justeru memperpanjang birokrasi yang mana berpotensi menimbulkan ketidakpastian hukum.

Hal cukup krusial, adalah pembayaran upah kepada buruh/pekerja yang tersangkut tindak pidana. Dalam perubahan Pasal 160 sebagaimana termuat pada point 49 Pasal 81 tentang Ketenagakerjaan dalam Undang-Undang Nomor 11 Tahun 2020 tentang Cipta Kerja, bahwa:

1) Dalam hal pekerja/buruh ditahan pihak yang berwajib karena diduga melakukan tindak pidana maka pengusaha tidak wajib membayar upah tetapi wajib memberikan bantuan kepada keluarga pekerja/buruh yang menjadi tanggungannya dengan ketentuan sebagai berikut:

a) untuk 1 (satu) orang tanggungan, 25\% (dua puluh lima perseratus) dari upah;

b) untuk 2 (dua) orang tanggungan, 35\% (tiga puluh lima perseratus) dari upah;

c) untuk 3 (tiga) orang tanggungan, $45 \%$ (empat puluh lima perseratus) dari upah;

d) untuk 4 (empat) orang tanggungan atau lebih, 50\% (lima puluh perseratus) dari upah.

2) Bantuan sebagaimana dimaksud pada ayat (1) diberikan untuk paling lama 6 (enam) bulan terhitung sejak hari pertama pekerja/buruh ditahan oleh pihak yang berwajib.

3) Pengusaha dapat melakukan pemutusan hubungan kerja terhadap pekerja/buruh yang setelah 6 (enam) bulan tidak dapat melakukan pekerjaan sebagaimana mestinya karena dalam proses perkara pidana sebagaimana dimaksud pada ayat (1).

4) Dalam hal pengadilan memutuskan perkara pidana sebelum masa 6 (enam) bulan sebagaimana dimaksud pada ayat (3) berakhir dan pekerja/

16 ibid. 
buruh dinyatakan tidak bersalah, pengusaha wajib mempekerjakan pekerja/ buruh kembali.

5) Dalam hal pengadilan memutuskan perkara pidana sebelum masa 6 (enam) bulan berakhir dan pekerja/buruh dinyatakan bersalah, pengusaha dapat melakukan pemutusan hubungan kerja kepada pekerja/buruh yang bersangkutan.

Pasal tersebut, memuat ketentuan yang sejatinya menimbulkanketidakjelasan ketentuan pidana apa yang dimaksud. Problemnya adalah bagaimana dengan seorang buruh yang tindakannya memperjuangkan hak-hak buruh atau menuntut perlindungan hukum atas buruh yang mendapat kertidakadilan, baik oleh perusahaan maupun karena protes terhadap kebijakan politik pemerintah yang abai terhadap hak-hak buruh. Lantas tindakan buruh tersebut, diproses secara hukum, apakah karena itu, buruh bersangkutan mesti dihentikan upahnya? Padahal, harus dibedakan antara perbuatan hukum kontraktual antara buruh dengan majikan terkait pekerjaan yang sesungguhnya, yang tidak boleh dicampuradukkan dengan tindakan-tindakan buruh yang karena untuk itu, ia sedang memperjuangkan hak-hak buruh.

Berbeda misalnya, kalau tindak pidana yang dilakukan sang buruh/pekerja terkait dengan pengrusakan terhadap fasilitas atau aset perusahaan atau tindak pidana pembunuhan atau penganiayaan terhadap jajaran pengurus perusahaan. Pada konteks demikian itu, barangkali bisa menjadi pertimbangan untuk menghentikan upah buruh/pekerja. Namun demi kepastian hukum, seharusnya Undang-Undang Cipta Lapangan Kerja, ada pengaturan tegas kualifikasi tindak pidana yang dimaksud, sehingga tidak menjadi justifikasi sepihak memberangus hak-hak upah buruh.

Problematika lain tentang uang pesangon, sebagaimana diatur dalam Pasal 81 point 44 perubahan Pasal 156 tentang Ketenagakerjaan mengatur bahwa:

1) Dalam hal terjadi pemutusan hubungan kerja, pengusaha wajib membayar uang pesangon dan/atau uang penghargaan masa kerja dan uang penggantian hak yang seharusnya diterima.

2) Uang pesangon sebagaimana dimaksud pada ayat (1) diberikan paling banyak sesuai ketentuan. 
Muh Sjaiful: Problematika Normatif Jaminan...

Ketentuan pasal tersebut, memuat frasa “... diberikan paling banyak sesuai ketentuan....". Sementara itu, regulasi sebelumnya yakni Undang-Undang Ketenagakerjaan Nomor 13 Tahun 2003 Pasal 156 menyebutkan hal tersebut dengan frasa 'paling sedikit'. Artinya, jika frasa 'paling banyak' tersebut digunakan, maka itu merupakan salah satu bentuk keberpihakan kepada pengusaha. Pihak pekerja akan dirugikan lantaran pihak pengusaha menjadi enggan untuk membayarkan pesangon. Jelas ini berimplikasi memangkas hak-hak pekerja untuk mendapatkan uang pesangon.

\section{Pemutusan Hubungan Kerja yang Bersifat Sepihak}

Pada undang-undang ketenagakerjaan dahulu, mengenai pemutusan hubungan kerja (PHK), terbangun asas bahwa segala upaya harus dilakukan agar jangan terjadi pemutusan hubungan kerja secara massif. Ketentuan tentang PHK dalam Undang-Undang Cipta Lapangan Kerja yang baru menegaskan bahwa PHK bertumpu kepada ketentuan sebagai berikut:

Pemberitahuan sebagaimana dimaksud dalam Pasal 151 ayat (2) tidak perlu dilakukan oleh Pengusaha dalam hal:

a) pekerja/buruh mengundurkan diri atas kemauan sendiri;

b) pekerja/buruh dan pengusaha berakhir hubungan kerjanya sesuai perjanjian kerja waktu tertentu;

c) pekerja/buruh mencapai usia pensiun sesuai dengan perjanjian kerja, peraturan perusahaan, atau perjanjian kerja bersama;atau

d) pekerja/buruh meninggal dunia.

Berdasarkan ketentuan tersebut maka nomenklatur PHK dikembalikan kepada ranah yang menjadi otoritas pihak pengusaha, sebagaimana kalimat yang menyebut bahwa "...tidak perlu dilakukan oleh Pengusaha dalam hal...", kalimat ini, tentu menurut penulis dapat membuat shock para pekerja yang di PHK tiba-tiba tanpa mendapatkan surat pemberitahuan tertulis...sudah diPHK oleh perusahaan. Yang paling riskan menurut pendapat penulis, yang tentu saja berpotensi menjadi pasal karet untuk me-PHK buruh atau pekerja sepihak adalah ketentuan Pasal 81 Point 42 tentang Penyisipan Pasal 154A, yang menyatakan sebagai berikut: 
Pasal 154A

1) Pemutusan hubungan kerja dapat terjadi karena alasan:

a) Perusahaan melakukan penggabungan, peleburan, pengambilalihan, atau pemisahan perusahaan;

b) perusahaan melakukan efisiensi;

c) perusahaan tutup yang disebabkan karena perusahaan mengalami kerugian;

d) perusahaan tutup yang disebabkan karena keadaan memaksa (force majeur);

e) perusahaan dalam keadaan penundaan kewajiban pembayaran utang;

f) perusahaan pailit;

g) perusahaan melakukan perbuatan yang merugikan pekerja/buruh;

h) pekerja/buruh mengundurkan diri atas kemauan sendiri pekerja/ buruh mangkir;

i) pekerja/buruh melakukan pelanggaran ketentuan yang diatur dalam perjanjian kerja, peraturan perusahaan, atau perjanjian kerja bersama;

j) pekerja/buruh ditahan pihak yang berwajib;

k) pekerja/buruh mengalami sakit berkepanjangan atau cacat akibat kecelakaan kerja dan tidak dapat melakukan pekerjaannya setelah melampaui batas 12 (dua belas) bulan;

1) pekerja/buruh memasuki usia pensiun; atau

m) pekerja/buruh meninggal dunia.

2) Selain alasan pemutusan hubungan kerja sebagaimana dimaksud pada ayat (1) dapat ditetapkan alasan pemutusan hubungan kerja lainnya dalam perjanjian kerja, peraturan perusahaan atau perjanjian kerja bersama.

3) Ketentuan lebih lanjut mengenai persyaratan dan tatacara pemutusan hubungan kerja diatur dengan Peraturan Pemerintah

Ketentuan yang tercantum itu, semakin menambah ambiguitas ketentuan tentang PHK bagi buruh/pekerja, sebab bertentangan dengan "asas menghindari PHK sedapat mungkin", sebagaimana terefleksi dalam Point 37 Pasal 81 UndangUndang Cipta Kerja bahwa “...Pengusaha, pekerja/buruh, serikat pekerja/serikat buruh, dan pemerintah, harus mengupayakan agar tidak terjadi pemutusan hubungan kerja...". Terdapat kontradiksi pengaturan tentang PHK, yakni point 37 melarang secara implisit tindakan sepihak pengusaha melakukan PHK sementara pada point lain, yakni point 42 Pasal 81 memberikan peluang cuku lebar bagi perusahaan untuk melakukan PHK secara sepihak. Kontradiksi point 37 dengan point 42 Pasal 81 tentang Ketenagakerjaan dalam Undang-Undang Nomor 11 
Muh Sjaiful: Problematika Normatif Jaminan...

Tahun 2020 tentang Cipta Kerja, tentu saja menimbulkan ketidakpastian hukum dalam kerangka perlindungan hak buruh/pekerja dari tindakan PHK yang dilakukan scara sepihak. ${ }^{17}$

Masih terkait PHK, sebagaimana analisis Kertas Kebijakan Catatan Kritis dan Rekomendasi Terhadap RUU Cipta Kerja, Fakultas Hukum Universitas Gadjah Mada, ${ }^{18}$ telah memberikan keleluasaan bagi pengusaha untuk melakukan PHK secara sepihak tanpa perlu melalui prosedur penyelesaian hubungan industrial dalam hal perusahaan ditutup karena alasan force majeur atau perusahaan dinyatakan pailit berdasarkan putusan pengadilan niaga. Pengecualian semacam itu tidak dikenal dalam undang-undang ketenagakerjaan sebelumnya, dan berpotensi menimbulkan gelombang PHK baru secara besar-besaran, terutama terkait perusahaan yang dinyatakan pailit.

\section{Filosofi Undang-Undang Cipta Kerja yang Berimplikasi Mengkebiri Jaminan}

\section{Hak-Hak Pekerja}

Menurut argumentasi penulis, problematika normatif yang mengkooptasi muatan Undang-Undang Nomor 11 Tahun 2020 tentang Cipta Kerja, sehingga berimplikasi mengkebiri jaminan hak-hak kaum buruh, yang justeru hanya menempatkan posisi kaum buruh/pekerja sebagai pihak yang dieksploitasi pihak majikan/pengusaha, sebab mendasarnya adalah filosofi asas yang mendasari tegaknya Undang-Undang Cipta lapangan Kerja tersebut, adalah pada standar berpikir investasi.

Keberadaan Undang-Undang Cipta Lapangan Kerja, sebagaimana dikutip dari situs Kementerian Koordinator Bidang Perekonomian Republik Indonesia, ${ }^{19}$ adalah guna menggaet kepercayaan investor masuk ke Indonesia dalam kerangka pemulihan ekonomi Indonesia ditengah ancaman pandemi covid-19. Tentu sebagai sebuah pernyataan resmi yang diungkapkan, maka paling tidak

\footnotetext{
${ }^{17}$ Sigit Riyanto, dkk, Kertas Kebijakan Catatan Kritis Dan Rekomendasi Terhadap RUU Cipta Kerja (Fakultas Hukum Universitas Gadjah Mada 2020).[9-10].

18 ibid.[9-10].

${ }^{19}$ Kementerian Koordinator Bidang Perekonomian Republik Indonesia, Loc.Cit.
} 
pernyataan tersebut merupakan ekstrak berpikir tentang hakikat dihadirkannya Undang-Undang Cipta lapangan kerja, yang bertumpu kepada asas investasi sebagai landasan fundamentalnya.

Dari titik pandang inilah, maka secara filosofis konseptual, Undang-Undang Nomor 11 Tahun 2020 tentang Cipta Kerja yang sebelumnya memantik polemik banyak kalangan, sebetulnya terpokok kepada tumpuan ekonomi liberalistik yang menjadi ratio legis mengapa undang-undang tersebut dilahirkan. Inilah penyebab sehingga sejumlah problematika normatif makin menjejali muatan pasal dalam Undang-Undang Nomor 11 Tahun 2020 tentang Cipta Kerja, yang implikasinya memangkas hak-hak dasar ekonomi para pekerja/buruh, yang justeru undang-undang ini menyimpan keberpihakan lebih besar bagi pihak pemilik modal/pengusaha.

Artinya, filosofi substansi dalam Undang-Undang Nomor 11 Tahun 2020 tentang Cipta Kerja, spesifik mengatur tentang ketenagakerjaan, tegak atas dasar orientasi investasi ekonomi, bukan tegak atas dasar profesionalisme dan pengembangan sumber daya manusia, sehingga apabila mencermati pasal-pasal revisi dan yang dihapus, tampak bahwa spirit undang-undang tidak menyentuh sama sekali upaya peningkatan kompetensi pekerja. Alih-alih pasal ini memberikan perlindungan pekerja. Undang-Undang Nomor 11 Tahun 2020 tentang Cipta Kerja justeru berpotensi membuat pasal ketenagakerjaan terpingggirkan, tergerus oleh kebutuhan investasi dan ekonomi. Padahal sejatinya, dalam hubungan industrial Pancasila, perlindungan pekerja merupakan bentuk tanggungjawab pemerintah.

Harus dipahami bahwa karakteristik ekonomi nasional Indonesia yang dikehendaki oleh Konstitusi UUD 1945, yakni ekonomi berbasis kekeluargaan, kebersamaan, dan demi kesejahteraan rakyat. Rujukannya, Pasal 33 Ayat 1 UUD 1945 menyatakan "Perekonomian disusun sebagai usaha bersama berdasar atas asas kekeluargaan”. Sedangkan Pasal 33 Ayat 2 menyatakan 'Cabang-cabang produksi yang penting bagi negara dan yang menguasai hajat hidup orang banyak dikuasai oleh negara'. Sementara Pasal 33 Ayat 3 bahwa "Bumi dan air dan kekayaan alam yang terkandung di dalamnya dikuasai oleh negara dan 
Muh Sjaiful: Problematika Normatif Jaminan...

dipergunakan untuk sebesar-besar kemakmuran rakyat". Tidak hanya itu, amanat konstitusi Pasal 34 UUD 1945, menghendaki kaum fakir miskin harus dijamin oleh negara. Yang tidak boleh dilupakan lagi adalah derivasi sistem ekonomi nasional Bangsa Indonesia yang harus merujuk Pasal 33 dan Pasal 34 UUD 1945, semestinya ditopang oleh Philosopsche Grondslag, Pancasila Sila ke-1, Ketuhanan Yang Maha Esa. Sehingga nilai-nilai transendental-relijius-spiritualistik, tidak boleh abai dalam pengaturan ekonomi nasional Bangsa Indonesia. Jawaban problematika ekonomi nasional yang mengedepankan kepada prinsip-prinsip syariah, juga seharusnya menjadi pedoman sebagai hak mayoritas masyarakat bangsa ini, yang muslim. Tentu saja Bangsa Indonesia, tidak boleh menafikan apalagi sampai "alergi" kepada penerapan ekonomi berbasis syariah. Formalisasi berbagai aturan ekonomi nasional berbasis syariah, seperti hadirnya perbankan syariah, BMT, produk halal MUI, pengakuan tentang zakat, eksistensi peradilan agama, seharusnya menjadi isyarat bahwa peluang penerapan syariah pada segmentasi yang lain, akan turut memberikan kontribusi perbaikan nasib bangsa ini menjadi lebih baik, termasuk juga masalah ketenagakerjaan.

Titik tumpu dari solusi atas problematika Undang-Undang Nomor 11 Tahun 2020 tentang Cipta Kerja, yang menuai polemik serta kontroversi, sebetulnya yang paling tepat adalah basis penormaan regulasi ketenagakerjaan bangsa Indonesia, dikembalikan kepada jati diri bangsa yang mencerminkan nilai-nilai relijius dan spiritual, demi terwujudnya kesejahteraan ekonomi masyarakat secara menyeluruh tanpa ada sekat-sekat kepentingan ekonomi kelompok dan oligarki.

\section{Kesimpulan}

Bertitik tumpu kepada pokok rumusan masalah yang menjadi isu utama penelitian ini, sebagaimana terurai pada paragraf pendahuluan, maka pokok kesimpulan penelitian bahwa muatan pasal-pasal tentang Ketenagakerjaan dalam Undang-Undang Nomor 11 Tahun 2020 tentang Cipta Kerja, masih menyimpan sejumlah problematika normatif, yakni belum memberikan jaminan kepastian hukum bagi perlindungan jaminan hak-hak pekerja, semisal penetapan upah 
yang layak dan kelayakan besaran pesangon. Begitu juga ketentuan tentang PHK, undang-undang hanya mengakomodir kepentingan pengusaha sehingga dapat berimplikasi PHK terhadap pekerja secara sepihak. Konsep filosofis UndangUndang Cipta lapangan Kerja, masih terkooptasi spirit ekonomi liberalistik yang menjadi basis fundamental kelahiran undang-undang tersebut sehingga Inilah yang menuai penolakan sebahagian besar masyarakat terhadap undang-undang cipta lapangan kerja tersebut.

Sehubungan dengan itu, penulis merekomendasikan lebih lanjut revisi Undang-Undang Nomor 11 Tahun 2020 tentang Cipta Kerja oleh pemerintah bersama DPR, hendaknya melibatkan partisipasi seluruh elemen masyarakat Indonesia, terutama melibatkan akademisi, LSM, dan Perserikatan Buruh Indonesia, gunanya untuk menghasilkan Undang-Undang Cipta Lapangan Kerja yang lebih memberikan jaminan hak-hak pekerja Indonesia yang sesuai dengan landasan filosofis jiwa bangsa Indonesia yang mencerminkan nilai-nilai relijius dan spiritual, demi terwujudnya kesejahteraan ekonomi masyarakat secara menyeluruh tanpa ada sekat-sekat kepentingan ekonomi kelompok dan oligarki.

\section{Daftar Bacaan}

\section{Buku}

Emile Durkheim, Sociology and Philosophy, Diterjemahkan oleh DF. Pocock dkk, Routledge Revivals (1953).

Irwansyah dan Ahsan Yunus, Penelitian Hukum (Pilihan Metode E Praktik Penulisan Artikel (Mirra Buana Media 2000).

Kementerian Koordinator Bidang Perekonomian Republik Indonesia, Omnibus Law Cipta Lapangan Kerja (2020).

Peter Mahmud Marzuki, Pengantar Ilmu Hukum (Kencana 2008).

S MFI, Ilmu Perundang-Undangan 1: Jenis Fungsi Dan Materi Muatan (Kanisius 2007).

Sigit Riyanto, dkk, Kertas Kebijakan Catatan Kritis Dan Rekomendasi Terhadap RUU Cipta Kerja (Fakultas Hukum Universitas Gadjah Mada 2020). 
Muh Sjaiful: Problematika Normatif Jaminan...

Sudikno Mertokusumo, Penemuan Hukum : Sebuah Pengantar (Liberty 2000).

Suparman Usman, Pokok-Pokok Filsafat Hukum (2010).

\section{Jurnal}

Atang Hermawan Usman, 'Kesadaran Hukum Masyarakat Dan Pemerintah Sebagai Faktor Tegaknya Negara Hukum Di Indonesia' (2014) 30 Jurnal Wawasan Hukum.

Christiani Widowati, 'Hukum Sebagai Norma Sosial Memiliki Sifat Mewajibkan' (2013) 4 Adil: Jurnal Hukum.

M Zulfa Aulia, 'Friedrich Carl Von Savigny Tentang Hukum: Hukum Sebagai Manifestasi Jiwa Bangsa”, , Volume 3 Nomor 1, h. 201-236, DOI: 10.22437/ Ujh.3.1' (2020) 3 Undang:Jurnal Hukum https://ujh.unja.ac.id/index.php/ home/article/view/95.

Muhammad Fakhrur Razy dan Muhammad Fedryansyah, 'Konflik Gerakan Masyarakat Sipil Dan Pemerintah Dalam Proses Penyusunan Rancangan Undang-Undang Omnibus Law 2020' (2020) 2 Jurnal Kolaborasi Resolusi Konflik.

Peni Jati Setyowati, 'Fungsi Filsafat, Agama, Ideologi Dan Hukum Dalam Perkembangan Politik Di Indonesia' (2016) 31 Yuridika.

\section{Laman}

Kementerian Keuangan Republik Indonesia, 'Dikunjungi' (RUU Cipta Lapangan Kerja Mulai Dibahas dengan Badan Legislasi DPR) https://www.kemenkeu. go.id/publikasi/berita/ruu-cipta-kerja-mulai-dibahas-dengan-badanlegislasi-dpr/.

How to cite: Muh Sjaiful, 'Problematika Normatif Jaminan Hak-Hak Pekerja Dalam Undang-Undang Nomor 11 Tahun 2020 Tentang Cipta Kerja' (2021) Vol. 4 No. 1 Media Iuris. 